\title{
Some biochemical responses of Salmo trutta caspius in response to
}

\section{transport stress}

\author{
R. Kazempoor ${ }^{1 *}$, S. Sh. Alavinezhad ${ }^{2}$ \\ ${ }^{1}$ Department of Biology, Roudehen Branch, Islamic Azad University, Roudehen, Iran \\ ${ }^{2}$ Department of Aquatic Animal Health, Faculty of Veterinary Medicine, University of Tehran, Tehran, Iran
}

Received: June 2020

Accepted: August 2020

\begin{abstract}
One of the most important and influential stress causing problem and secondary diseases in fish is transport stress. The aim of this study was to evaluate the physiological effects of acute stress of fish transportation on some biochemicals in Salmo trutta caspius. A total of 100 fish were transported in plastic bags for $6 \mathrm{~h}$ and then released in 300-1 tanks. Blood samples were taken after 6, 12, 24 and $48 \mathrm{~h}$ after a 6-h transportation $(n=15)$. Based on the results, blood glucose increased compared to the basal value $(\mathrm{p}<0.05)$ after $6 \mathrm{~h}$ but the value was decreased at 12 and 24 $\mathrm{h}$ compared to that of $6 \mathrm{~h}$. Cortisol value was increased significantly $(\mathrm{p}<0.05)$ in all sampling times. Unexpectedly, protein content was significantly increased $(p<0.05)$ at $24 \mathrm{~h}$. On the other hands, other parameters uch as $\mathrm{Na}^{+}, \mathrm{Cl}^{-}$, $\mathrm{K}^{+}$, did not show a significant variation after transportation $(\mathrm{p}>0.05)$.
\end{abstract}

Keywords: Salmo trutta caspius, stress, transport, blood, biochemical

${ }^{*}$ Correspondence R. Kazempoor, Department of Biology, Roudehen Branch, Islamic Azad University, Roudehen, Iran (e-mail: r.kazempoor@riau.ac.ir).

\section{Introduction}

The physiology of fish can be affected by water parameters changes. Water parameters can unpleasantly alter during fish transport. Handling and transportation are the crucial predisposing factors provoke more acute or chronic stress in fish (Meinelt et al., 2008). Stress is well-known to be a non-specific response of animal to any environmental stimulation out of normal level (Wu et al., 2015). Handling of live fish, particularly within hatchery phase, is a routine technique in aquaculture management.different types of acute and chronic stress, such as fluctuation in water temperature, dissolved oxygen depletion, increase of ammonia, alteration in $\mathrm{pH}$ and occasionally salinity were performed by handling, packing, shipping, stocking in pond, are expected and result in unpredictable mortality and loss (Pan et al., 2010).

Fish movement is a world essential practive, concerning several aims: (i) human feeding (Marçalo et al., 2008; Reglero et al., 2013); (ii) handling the fry from hatchery centers to growout ponds (de Abreu et al., 2008) and fishing in lake (angling); (iii) handling of wild 
fish for rearing practices (Marçalo et al., 2008; Oyoo-Okoth et al., 2011), stocking of fish for rehabilitation programmes (Gomes et al., 2003), for unrestricted aquaria of city (Correia et al., 2008; Harmon, 2009), ornamental activities (Brinn et al., 2012; Gomes et al., 2009; Wright et al., 2007), or even for study (Corrêa et al., 2014).

Aquaculture management often described handling for different aims (Stieglitz et al., 2012). Suitable handling with determined regulations and less stressful procedures are very crutial for fish aquaculturists because they can promote the benefit of their practices by retarding stress results in fish mortality (Gomes et al., 2003). Research on farmed animals that characterize responses to stress make aquaculture to be an economic activity with higher profitability (Sampaio and Freire, 2016). Also Stress performs by handling and movement usually result in loss of fish quality and marketing particularly due to losing freshness, lack of appropriate muscle texture, loss of filet weight, rigor mortis, muscle $\mathrm{pH}$ alteration and water holding capacity (Jittinandana et al., 2005). Although, Caspian brown trout (Salmo trutta caspius) is known as endangered species, naturally its habitat located in southern basin of Caspian Sea. Nowadays, it has been ehabilitated, their cultured stocks gradually increased and maintained for enhancement, protection of wild populations and aquaculture objectives (Sarvi et al., 2006).

The aim of this study was to determine stress responses including some biochemical parameters of Salmo trutta caspius to handling and transport.

\section{Material and methods}

\section{Fish and rearing condition}

The experiment was carried out using 100 Salmo trutta caspius transported from Cold Water Fishes Research Center, Tonekabon. The initial Fish weight and total length were $16.99 \pm 2.35 \mathrm{~cm}$ and $54.18 \pm 16.26 \mathrm{~g}$, respectively. They were then transported in plastic bags at a density of $1 \mathrm{~kg} \mathrm{~m}^{-3}$, reached the research farm in Inland Water Aquaculture Research Center, Bandar-e Anzali, after $6 \mathrm{~h}$ and were promptly stocked in 300-L tanks. Water quality parameters were monitored and recorded at the beginning and the end of the study (Table 1).

Table 1. Water quality parameters during the period of study

\begin{tabular}{ll}
\hline Temperature $\left({ }^{\circ} \mathrm{C}\right)$ & 19 \\
Dissolved oxygen $\left(\mathrm{mg} \mathrm{L}^{-1}\right)$ & $6.9 \pm 0.82$ \\
Ammonium $\left(\mathrm{mg} \mathrm{L}^{-1}\right)$ & $0.91 \pm 0.21$ \\
$\mathrm{pH}$ & $7.64 \pm 0.04$ \\
\hline
\end{tabular}

Oxygen content and temperature were measured in situ (WTW pH 235, Germany), and $\mathrm{pH}$ and $\mathrm{NH}^{4+}$ were measured in a laboratory using commercial test kits from Aquamerck (Merck, Germany).

\section{Sampling design}

The study was based on a blood sample that was prepared randomly at sampling times. The fish were anesthetized and blood samples were taken by heparinized syringes from caudal vein 
of 15 fish, at $0,6,12,24$ and $48 \mathrm{~h}$ after transportation. The fish were stunned and discarded after sampling. The total length and body weight were also measured.

\section{Biochemical assay}

For biochemical assay, blood samples were immediately transferred to sterile tubes and the serum was separated by centrifugationat at $5000 \mathrm{~g}$ for 5 min (Hettich D7200, Germany). Thus, plasma separated and stored at $-20{ }^{\circ} \mathrm{C}$ until use. Serum total protein was measured by Biuret method using biochemistry kit (ZiestChemie, Iran) using a spectrophotometer (Model M70; Bausch \& Lomb Pharma NV, Brussel, Belgium) at $540 \mathrm{~nm}$. Also glucose and cortisol were measured in plasma, applying diagnostic colorimetric kits (ZiestChemieIran) using a spectrophotometer. Serum value of $\mathrm{Na}^{+}, \mathrm{K}^{+}$and $\mathrm{Cl}^{-}$were determined by flame photometric and calorimetrically method, separately and cortisol was assayed by RIA and Immunotech kits (IM 1841, Prague, Czech Republic).

\section{Statistical analyses}

data are given as mean $\pm \mathrm{SD}$. The One-Way ANOVA test was used to determine the differences among groups followed by Duncan's multiple comparisons test while a significant difference was observed $(\mathrm{p}<0.05)$ in the ANOVA analysis using SPSS 16.0 software (Chicago, USA).

\section{Results}

Table 1 shows the normal values of water quality parameters during the period of the study. No mortality was recorded among the fish during the experimental period. The results (mean \pm SD) of analysis of the biochemical parameters in Salmo trutta caspius are presented in Figure 1-3 and Tables 2.

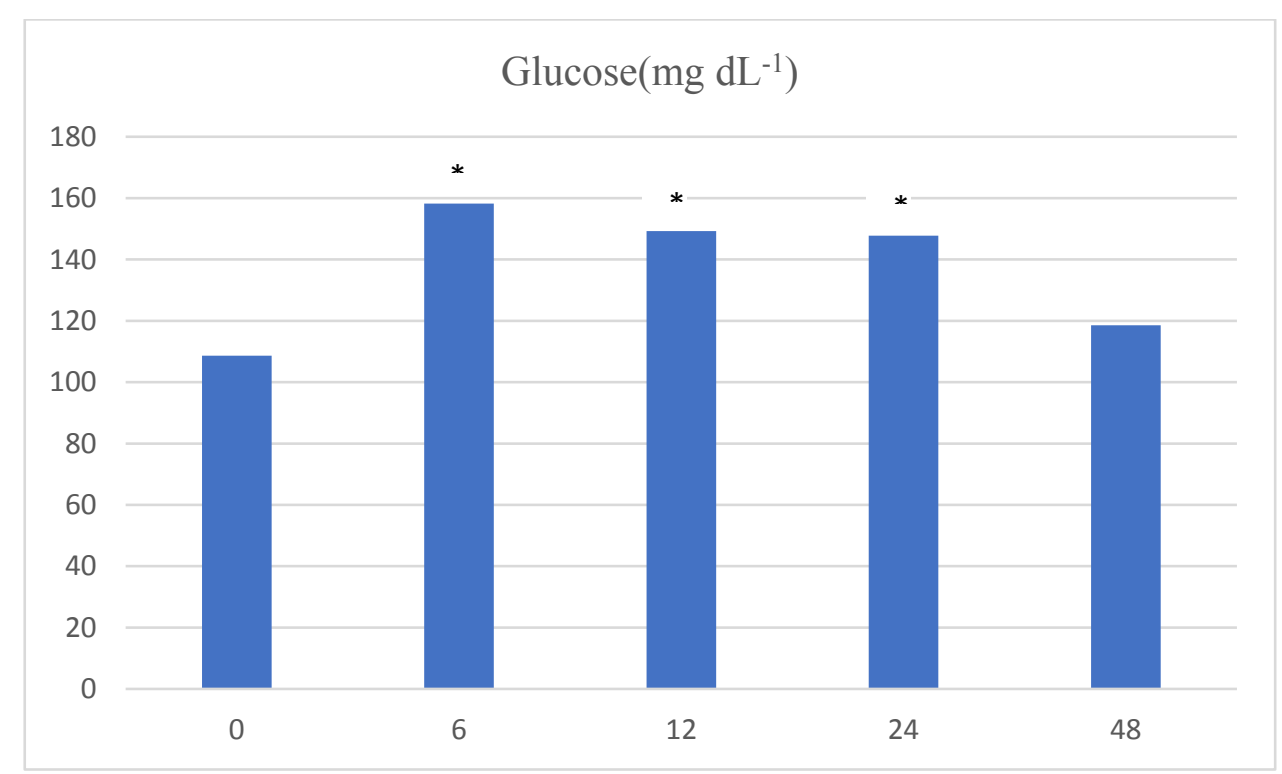

Figure 1. Effect of transportation on blood glucose value at different times. ${ }^{*}$ shows $\mathrm{p}<0.05$. 


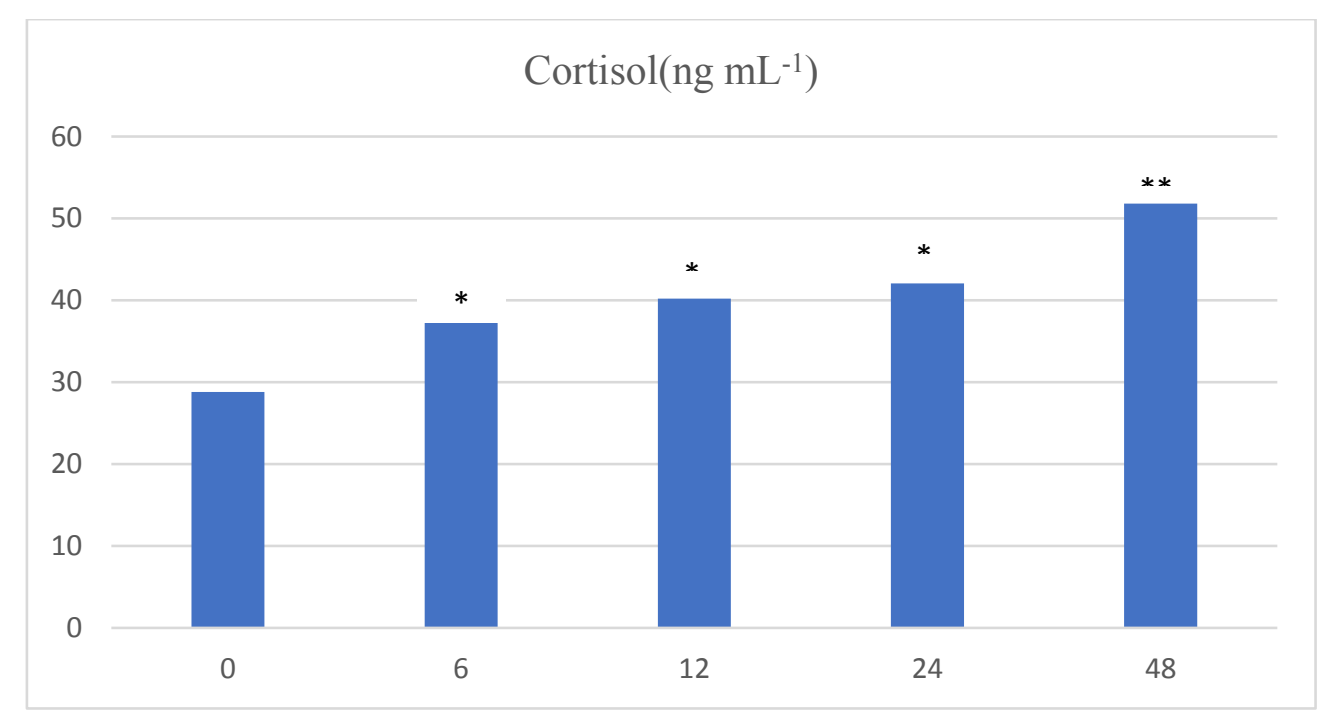

Figure 2. Effect of transportation on blood cortisol value at different times. *,** shows $\mathrm{p}<0.05$.

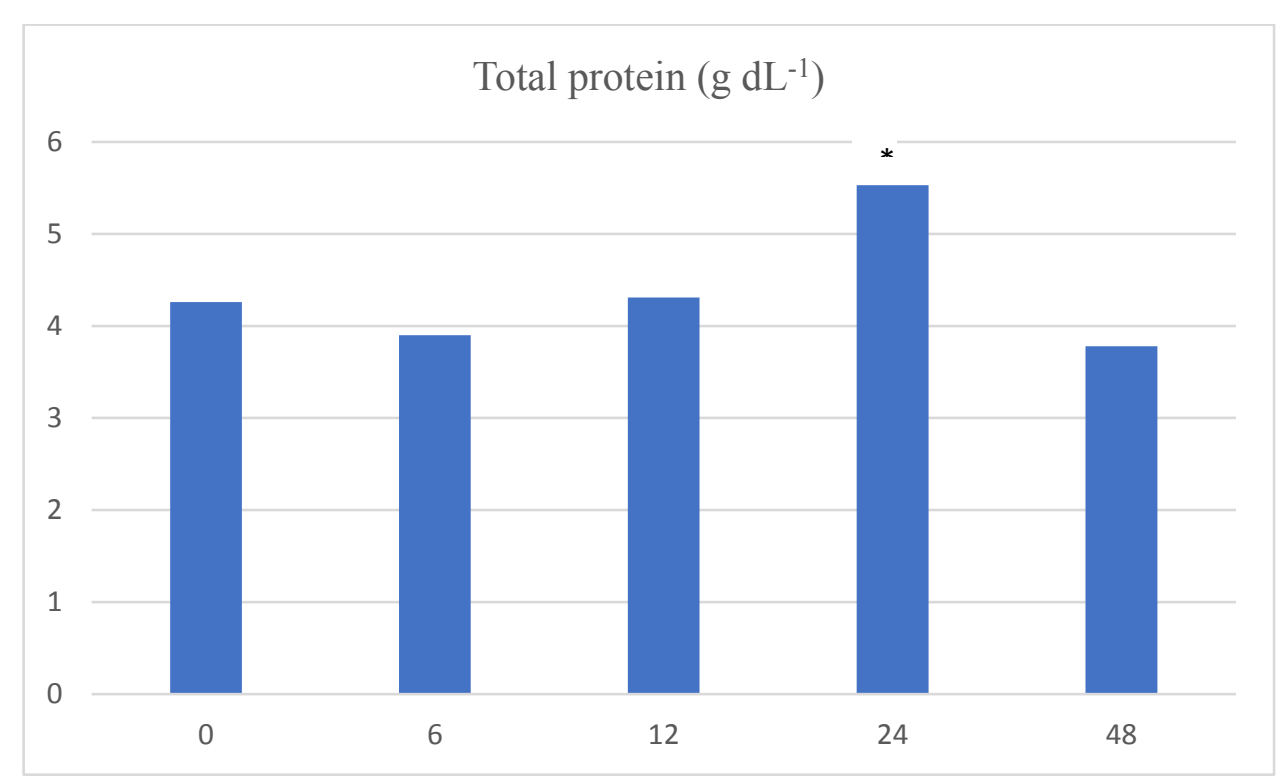

Figure 3. Effect of transportation on total protein value at different times. * shows $p<0.05$.

Table 2. Effect of transportation on blood biochemical parameters

\begin{tabular}{llllll}
\hline & $\mathbf{0}$ & $\mathbf{6}$ & $\mathbf{1 2}$ & $\mathbf{2 4}$ & $\mathbf{4 8}$ \\
\cline { 2 - 6 } $\mathrm{Na}^{+}\left(\mathrm{mEq} \mathrm{L}^{-1}\right)$ & $166.8 \pm 13.07^{\mathrm{a}}$ & $166.4 \pm 13.24^{\mathrm{a}}$ & $168.50 \pm 14.05^{\mathrm{a}}$ & $167.25 \pm 7.13^{\mathrm{a}}$ & $166.4 \pm 9.23^{\mathrm{a}}$ \\
$\mathrm{Cl}^{-}\left(\mathrm{mEq} \mathrm{L}^{-1}\right)$ & $112.5 \pm 5.19^{\mathrm{a}}$ & $109.4 \pm 3.64^{\mathrm{a}}$ & $107.25 \pm 2.50^{\mathrm{a}}$ & $111 \pm 3.60^{\mathrm{a}}$ & $114.20 \pm 4.08^{\mathrm{a}}$ \\
$\mathrm{K}^{+}\left(\mathrm{mEq} \mathrm{L}^{-1}\right)$ & $2.16 \pm 0.69^{\mathrm{a}}$ & $2.26 \pm .047^{\mathrm{a}}$ & $2.90 \pm 0.79^{\mathrm{a}}$ & $2.59 \pm 0.28^{\mathrm{a}}$ & $2.57 \pm 0.35^{\mathrm{a}}$ \\
\hline
\end{tabular}

Values are given as mean \pm SD. Different letters denote significant differences $(p<0.05)$ between values of each treatment.

Blood glucose was increased $(\mathrm{p}<0.05)$ after $6 \mathrm{~h}\left(158.21 \pm 30.05 \mathrm{mg} \mathrm{dL}^{-1}\right)$ compared to the basal values $\left(108.61 \pm 27.75 \mathrm{mg} \mathrm{dL}^{-1}\right.$. At 12 $\left(149.0 \pm 0.25 \mathrm{mg} \mathrm{dL}^{-1}\right)$ and $24 \mathrm{~h}(147.0 \pm 0.75 \mathrm{mg}$ $\left.\mathrm{dL}^{-1}\right)$ of the experiment, the values were decreased compared to samples were analazed 
after $6 \mathrm{~h}\left(108.6 \mathrm{mg} \mathrm{dL}^{-1}\right)$. Unexpectedly, the value of the samples were remarkably at 48 hour (118.52 \pm 9.03$)$, it was insignificantly $(p>0.05)$ higher than the basal values $(149.25 \pm 9.94 \mathrm{mg}$ $\left.\mathrm{dL}^{-1}\right)$. Cortisol significantly increased $(\mathrm{p}<0.05)$ in all sampling times $(6,12,24$ and $48 \mathrm{~h})$ compared to control values. In the 48-hour sampling, this rate $\left(51.80 \pm 11.57 \mathrm{ng} \mathrm{mL}^{-1}\right)$ was significantly $(\mathrm{p}<0.05)$ higher than all sampling times carrying out at $0,6,12$ and $24 \mathrm{~h}$ $(28.8 \pm 7.92, \quad 37.38 \pm 2.78, \quad 40.21 \pm 4.62$, $42.05 \pm 5.73$, respectively). Protein content showed no significant difference $(p>0.05)$ among the values of sampling times $0,6,12$ $\left(4.26 \pm 0.68, \quad 3.9 \pm 0.47, \quad 4.31 \pm 0.72 \quad \mathrm{~g} \quad \mathrm{dL}^{-1}\right.$, respectively) and significantly increased $\left(5.53 \pm 0.54 \mathrm{~g} \quad \mathrm{dL}^{-1}, \quad \mathrm{p}<0.05\right)$. Its value significantly $(\mathrm{p}<0.05)$ decreased at $48 \mathrm{~h}$ $\left.3.78 \pm 0.54 \mathrm{~g} \mathrm{dL}^{-1}\right)$. and did not show a significant difference $(p>0.05)$ in comparison to the value of the samples were analyzed at $0,6,12$ and 24 h. On the other hand, blood $\mathrm{Na}^{+}, \mathrm{Cl}^{-}$and $\mathrm{K}^{+}$ content did not show a significant difference $(\mathrm{p}>0.05)$ at different times (Tables 2).

\section{Discussion}

As fish are vulnerable to sudden changes in environmental parameters, necessary care should be considered. During the period of study, water quality parameters were checked and it should be expressed that the transport media had no adverse effect on fish condition.

After exposure to stress, activation of hypothalamo-pituitary-interrenal response eventually result in an increase in the plasma cortisol level (Herman et al., 2011). This increase is also observed in the present study. Fish, like other vertebrates cortisol, plays a crucial role in the restoration of homeostasis during stress or afterwards (Goos and Consten, 2002). An upsurge in the levels of plasma cortisol is a primary response to stress (Kalamarz-Kubiak, 2018). In this study, the plasma cortisol level in fish slightly increased after $6 \mathrm{~h}$ of transport. This initial increase may be caused by netting within pre-transport handling that is similar with other findings (Dobšíková et al., 2009; Ruane et al., 2002). Plasma cortisol also grew up lightly during transport, which could be continued with the extension of transport time reported while they reared in a red drum (Tacchi et al., 2015).

In this study, glucose was increased significantly at the time of capture and decreased after $12 \mathrm{~h}$, but did not return to basal values. As stated, the response of fish to a stress is described with a series of biochemical and physiological alterations, which in turns results in discharging stress hormones including cortisol into the blood (Stankevičiūtè et al., 2018). These alterations promote the tolerance of a fish to manage stress in order to keep its normal condition or homeostatic state (Barton, 2002). As glucose mobilization is controlled primarily by catecholamines, an increase of plasma catecholamine level almost is occurred after wild capture (Pankhurst, 2011). it can be concluded that the increase of plasma glucose levels recorded from fish samples at the beginning of this study caused by stress-induced changes.

Also It had been showed that blood osmolality and electrolyte concentrations are 
affected by fish handling and transportation (Urbinati et al., 2004). This Osmotic fluctuation is caused directly by changes in branchial permeability to water and electrolytes (Henry et al., 2012). In this study, plasma $\mathrm{Na}^{+}, \mathrm{K}^{+}$and $\mathrm{Cl}^{-}$ didn't change during the experiment. Similar to vertebrate brain, fish brain also coordinates the spatial and temporal physiological activities through the activation/inactivation of their specific neuronal groups. The membrane-bound of $\mathrm{Na}+\mathrm{K}+$-ATPase (NKA) that maintains the asymmetric distribution of $\mathrm{Na}^{+}$and $\mathrm{K}^{+}$in neuronal cells shows synaptic and neuronal activity and is connected to neuronal functions (Foo et al., 2012) and the increased NKA activity after hypoxia stress observed in another study (Peter and Simi, 2017). On the contrary, induction of hypoxia stress in immune-challenged fish brain shows a shift in the pattern of NKA activity, and this further points that hypoxia stress has a direct control on brain $\mathrm{Na}^{+} / \mathrm{K}^{+}$-pump function (Peter and Simi, 2017). Unlike the present study, an increase of ion content in blood had been described in other species (Barcelos et al., 2020; Narra et al., 2017).

Although the protein and glucose content of Salmo truuta caspius tended to be decreased after $24 \mathrm{~h}$ post stress but cortisol did not show any decrease up to $48 \mathrm{~h}$ post stress. Thus, it is concluded that the transport stress in this species could be prolonged up to $48 \mathrm{~h}$ after transport stress.

\section{Conflicts of interest}

None of the authors has any conflicts of interest to declare.

\section{References}

Barcelos, R. C. S., Rosa, H. Z., Roversi, K., dos Santos Tibúrcio-Machado, C., Inchaki, P. T., Burger, M. E. and de Souza Bier, C. A., 2020. Apical periodontitis induces changes on oxidative stress parameters and increases $\mathrm{Na}+/ \mathrm{K}+$-ATPase activity in adult rats. Archives of Oral Biology, 118, 104849.

Barton, B. A., 2002. Stress in fishes: a diversity of responses with particular reference to changes in circulating corticosteroids. Integrative and comparative biology, 42(3), 517-525.

Brinn, R., Marcon, J., McComb, D., Gomes, L., Abreu, J. and Baldisseroto, B., 2012. Stress responses of the endemic freshwater cururu stingray (Potamotrygon cf. histrix) during transportation in the Amazon region of the Rio Negro. Comparative Biochemistry and Physiology Part A: Molecular \& Integrative Physiology, 162(2), 139-145.

Corrêa, L. L., Souza, G. T., Takemoto, R. M., Ceccarelli, P. S. and Adriano, E. A., 2014. Behavioral changes caused by Austrodiplostomum spp. in Hoplias malabaricus from the São Francisco River, Brazil. Parasitology research, 113(2), 499503.

Correia, J. P., Graça, J. T. and Hirofumi, M., 2008. Long- term transportation, by road and air, of Devil- ray (Mobula mobular), Meagre (Argyrosomus regius), and Ocean Sunfish (Mola mola). Zoo Biology, 27(3), 234-250. 
de Abreu, J. S., Sanabria-Ochoa, A. I., Gonçalves, F. D. and Urbinati, E. C., 2008. Stress responses of juvenile matrinxã (Brycon amazonicus) after transport in a closed system under different loading densities. Ciencia Rural, 38(5), 1413-1417.

Dobšíková, R., Svobodova, Z., Blahova, J., Modra, H. and Velíšek, J., 2009. The effect of transport on biochemical and haematological indices of common carp Cyprinus carpio L.). Czech Journal of Animal Science, 54(11), 510-518.

Foo, J.-N., Liu, J.-J. and Tan, E.-K., 2012. Whole-genome and whole-exome sequencing in neurological diseases. Nature Reviews Neurology, 8(9), 508-517.

Gomes, L. C., Brinn, R. P., Marcon, J. L., Dantas, L. A., Brandão, F. R., De Abreu, J. S., Lemos, P. E. M., McComb, D. M. and Baldisserotto, B., 2009. Benefits of using the probiotic Efinol ${ }^{\circledR}$ L during transportation of cardinal tetra, Paracheirodon axelrodi (Schultz), in the Amazon. Aquaculture Research, 40(2), 157-165.

Gomes, L. C., Roubach, R., Araujo- Lima, C. A., Chippari- Gomes, A. R., Lopes, N. P. and Urbinati, E. C., 2003. Effect of fish density during transportation on stress and mortality of juvenile tambaqui Colossoma macropomum. Journal of the World Aquaculture society, 34(1), 76-84.

Goos, H. T. and Consten, D., 2002. Stress adaptation, cortisol and pubertal development in the male common carp, Cyprinus carpio.
Molecular and Cellular Endocrinology, 197(12), 105-116.

Harmon, T. S., 2009. Methods for reducing stressors and maintaining water quality associated with live fish transport in tanks: a review of the basics. Reviews in Aquaculture, l(1), 58-66.

Henry, R. P., Lucu, C., Onken, H. and Weihrauch, D., 2012. Multiple functions of the crustacean gill: osmotic/ionic regulation, acidbase balance, ammonia excretion, and bioaccumulation of toxic metals. Frontiers in Physiology, 3, 431.

Herman, J. P., McKlveen, J. M., Ghosal, S., Kopp, B., Wulsin, A., Makinson, R., Scheimann, J. and Myers, B., 2011. Regulation of the hypothalamic- pituitary- adrenocortical stress response. Comprehensive Physiology, 6(2), 603-621.

Jittinandana, S., Kenney, P., Mazik, P., Danley, M., Nelson, C., Kiser, R. and Hankins, J., 2005. Transport and stunning affect quality of Arctic char fillets. Journal of Muscle Foods, 16(3), 274-288.

Kalamarz-Kubiak, H., 2018. Cortisol in Correlation to Other Indicators of Fish Welfare. Edited by Ali Gamal Al-kaf, 155.

Marçalo, A., Pousão Ferreira, P., Mateus, L., Duarte Correia, J. and Stratoudakis, Y., 2008. Sardine early survival, physical condition and stress after introduction to captivity. Journal of Fish Biology, 72(1), 103-120. 
Meinelt, T., Schreckenbach, K., Pietrock, M., Heidrich, S. and Steinberg, C. E., 2008. Humic substances. Environmental Science and Pollution Research, 15(1), 17.

Narra, M. R., Rajender, K., Reddy, R. R., Murty, U. S. and Begum, G., 2017. Insecticides induced stress response and recuperation in fish: biomarkers in blood and tissues related to oxidative damage. Chemosphere, 168, 350357.

Oyoo-Okoth, E., Cherop, L., Ngugi, C. C., Chepkirui-Boit, V., Manguya-Lusega, D., AniSabwa, J. and Charo-Karisa, H., 2011. Survival and physiological response of Labeo victorianus (Pisces: Cyprinidae, Boulenger 1901) juveniles to transport stress under a salinity gradient. Aquaculture, 319(1-2), 226-231.

Pan, C. H., Chien, Y. H. and Wang, Y. J., 2010. The antioxidant capacity response to hypoxia stress during transportation of characins (Hyphessobrycon callistus Boulenger) fed diets supplemented with carotenoids. Aquaculture Research, 41(7), 973-981.

Pankhurst, N., 2011. The endocrinology of stress in fish: an environmental perspective. General and comparative endocrinology, 170(2), 265-275.

Peter, M. S. and Simi, S., 2017. Hypoxia Stress Modifies $\mathrm{Na}+/ \mathrm{K}+$-ATPase, $\mathrm{H}+/ \mathrm{K}+$-ATPase, $\mathrm{Na}+\mathrm{NH}$ 4+-ATPase, and nka 1 Isoform Expression in the Brain of Immune-Challenged Air-Breathing Fish. Journal of Experimental Neuroscience, 11, 1-18.
Reglero, P., Balbín, R., Ortega, A., AlvarezBerastegui, D., Gordoa, A., Torres, A. P., Moltó, V., Pascual, A., De La Gándara, F. and Alemany, F., 2013. First attempt to assess the viability of bluefin tuna spawning events in offshore cages located in an a priori favourable larval habitat. Scientia Marina, 77(4), 585-594.

Ruane, N. M., Carballo, E. C. and Komen, J., 2002. Increased stocking density influences the acute physiological stress response of common carp Cyprinus carpio (L.). Aquaculture Research, 33(10), 777-784.

Sampaio, F. D. and Freire, C. A., 2016. An overview of stress physiology of fish transport: changes in water quality as a function of transport duration. Fish and Fisheries, 17(4), 1055-1072.

Sarvi, K., Niksirat, H., Amiri, B. M., Mirtorabi, S., Rafiee, G. and Bakhtiyari, M., 2006. Cryopreservation of semen from the endangered Caspian brown trout (Salmo trutta caspius). Aquaculture, 256(1-4), 564-569.

Stankevičiūtè, M., Sauliutè, G., Makaras, T., Markuckas, A., Virbickas, T. and Baršienè, J., 2018. Responses of biomarkers in Atlantic salmon (Salmo salar) following exposure to environmentally relevant concentrations of complex metal mixture $(\mathrm{Zn}, \mathrm{Cu}, \mathrm{Ni}, \mathrm{Cr}, \mathrm{Pb}$, Cd). Part II. Ecotoxicology, 27(8), 1069-1086.

Stieglitz, J. D., Benetti, D. D. and Serafy, J. E., 2012. Optimizing transport of live juvenile cobia (Rachycentron canadum): effects of salinity and shipping biomass. Aquaculture, 364, 293-297. 
Tacchi, L., Lowrey, L., Musharrafieh, R., Crossey, K., Larragoite, E. T. and Salinas, I., 2015. Effects of transportation stress and addition of salt to transport water on the skin mucosal homeostasis of rainbow trout (Oncorhynchus mykiss). Aquaculture, 435, 120-127.

Urbinati, E. C., de Abreu, J. S., da Silva Camargo, A. C. and Parra, M. A. L., 2004. Loading and transport stress of juvenile matrinxã (Brycon cephalus, Characidae) at various densities. Aquaculture, 229(1-4), 389-400.
Wright, K., Woods, C., Gray, B. and Lokman, P., 2007. Recovery from acute, chronic and transport stress in the pot- bellied seahorse Hippocampus abdominalis. Journal of Fish Biology, 70(5), 1447-1457.

Wu, H., Aoki, A., Arimoto, T., Nakano, T., Ohnuki, H., Murata, M., Ren, H. and Endo, H., 2015. Fish stress become visible: A new attempt to use biosensor for real-time monitoring fish stress. Biosensors and Bioelectronics, 67, 503-510. 